\title{
Prevalence and distribution of human malarial infection in district Multan, Punjab, Pakistan
}

\section{Muhammad Zafar ${ }^{*}$, Iram Mushtaq ${ }^{2}$, Samrah Masud ${ }^{3}$, Muhammad Zahid $\mathrm{Khan}^{4}$, Muhammad Khalil Ahmad Khan ${ }^{5}$ and Asmatullah ${ }^{6}$}

1. Postgraduate Department of Zoology, Govt. Emerson College, Multan-Pakistan

2. Department of Pahtology, University of Veterinary and Animal Sciences, Lahore-Pakistan

3. Department of Zoology, Institute of Pure \& Applied Biology, Bahauddin Zakariya University, Mutan-Pakistan

4. House Officer, Mediccal Unit 04, Bahawal Victoria Hospital and Quid-e-Azam Medical College, Bahawalpure-

Pakistan

5. Department of Zoology, Govt. College of Science, Wahdat Road, Lahore-Pakistan

6. Department of Zoology, University of The Punjab, Quid-e-Azam Campus, Lahore-Pakistan

*Corresponding author's email: m.zafar1214@gmail.com

Citation

Muhammad Zafar, Iram Mushtaq, Samrah Masud, Muhammad Zahid Khan, Muhammad Khalil Ahmad Khan and Asmatullah. Prevalence and distribution of human malarial infection in district Multan, Punjab, Pakistan. Pure and Applied Biology. Vol. 8, Issue 1, pp873-881. http://dx.doi.org/10.19045/bspab.2019.80029

\begin{tabular}{llll}
\hline \hline Received: 16/11/2018 & Revised: 21/02/2019 & Accepted: 06/03/2019 & Online First: 14/03/2019 \\
\hline \hline
\end{tabular}

\section{Abstract}

The present study was undertaken during 2015-17 with the objective to provide data of malarial infections in human population based on incidences in twenty different localities of district Multan, Punjab, Pakistan. The blood slides of suspected patients were studied to identify the malarial parasites. Slide positivity was found to be 1478 (39.20\%) out of 3770 and Plasmodium vivax infection was 905 (61.23\%), Plasmodium falciparum 425 (28.75\%) and mixed species ( $P$. vivax and $P$. falciparum) 148 (10.01\%) were identified. In the month of December, 150 cases $(73.25 \%)$ of $P$. vivax infection counted to be the highest, whereas, 42 cases $(58.33 \%)$ of $P$. vivax in the month of September were recorded. The $P$. falciparum infection remained highest in the month of August with 58 cases (25.66\%) and lowest in the month of May with $24(23.76 \%)$. Similarly infection of mixed species remained highest $30(13.27 \%)$ in August and lowest $7(7.60 \%)$ in the month of February. Infection in male was highest 850 (57.51\%) and female was lowest 628 (42.48\%). No incidence of Plasmodium ovale and Plasmodium malariae infection was to be observed in this study. The results of present research work concluded that $P$. vivax and $P$. falciparum are serious health hazards which can ultimately lead to serious cerebral malaria problems. However, no association was found between age group, sex and type of infection. Therefore, it can be concluded that the incidence of any type of infection may happened from person to person of any age group and in any sex.

Keywords: Incidence; Infection; Multan; Mixed species; Plasmodium falciparum; Plasmodium vivax

\section{Introduction}

Malaria is known as a major parasitic diseases in all over the world. Over 225 million malarial cases were reported in 2011. Species Plasmodium falciparum is the most severe form of malaria parasite. Mostly it is transmitted through the bite of an infected female mosquito known as Anopheles when it feeds on human beings [1].

Malaria is known as one of the most devastating disease throughout in the world and 4 billion people live under the threat of malaria in 25 endemic countries [2] and each 
year it kills over a million mostly children [3].

Malaria is considered as one of the major poverty disease and needs to be eradicated. Due to consequences of malaria, children below five years and pregnant women are felt hardest. With the lack of hygiene and proper nutrition, a child dies from malaria after every thirty seconds [4].

At CMH, Multan [5] 125 cases of Plasmodium falciparum malaria were studied to evaluate seasonal variations and modes of transmission. The incidence of Plasmodium falciparum remained high among troops during the months of August to November. In general population of district Buner, [6] studied prevalence of malaria and recorded highest rate of infection $(11.71 \%)$ in the month of August while in March the lowest rate of infection (3.8\%) was noted. In pediatric age group 250 cases of malaria were investigated by [7] who found high rate of infection of Plasmodium vivax (63.2\%) as compared to infection of Plasmodium falciparum (35\%). In Karachi including other areas of province Sindh, Malaria was studied by [8] it was observed that infection of Plasmodium vivax were more than two times higher than the infection of Plasmodium falciparum. In many districts of the province Sindh [9] fond that Plasmodium falciparum ratio was increasing day by day. In North West Frontier Province (NWFP) malaria was studied by [10] who observed cerebral malaria as more common infection in males and for pregnant females it was highly vulnerable. In another study [7] among the 165 cases of malarial parasite in children, 145 cases were diagnosed as Plasmodium vivax and 20 cases of Plasmodium falciparum. At Ayub Teaching Hospital Abbottabad the study regarding the pattern of malarial infection by [11] 1998 patients were screened and $150(7.5 \%)$ were found to be infected by Plasmodium vivax in $72.2 \%$ and Plasmodium falciparum in $24.3 \%$ cases.
In Balochistan, cerebral malaria is declared as a major community problem. In a study [12] to observed epidemiology of cerebral malaria and its mortality in patients in Quetta City, $63 \%$ cases of cerebral malaria in children while $37 \%$ cases in adults were investigated. Furthermore, in a study of urban and rural areas of Quetta district $[13,14]$ in 2003 and 2004 in the age group of 22 and above, higher rate of incidence of Plasmodium falciparum (17.8\%, 16.4\%, respectively) were noted. A recent report about malaria from Pakistan, which was published in 2017, evidence sustained decrease in the number of cases, but however we are unable to achieve the target in all over the world about malarial eradication [15].

Many studies have been conducted to investigate the knowledge, attitudes and practices of people with respect to malaria but only few to know the cause of malaria. Investigating the rate of prevalence of malarial parasites in human population of the Multan district was the objective of present study.

\section{Materials and methods}

Multan is located in the southern part of the province Punjab, Pakistan. Multan is known as an arid area with very hot summer and cold winters. In winter the average lowest temperature is $4.4^{\circ} \mathrm{C}\left(40.1^{0} \mathrm{~F}\right)$ while in summer the highest average temperature recorded is $42.2^{0} \mathrm{C}\left(108.1^{0} \mathrm{~F}\right)$.

Different localities of Multan district were studied during August 2015 to July 2017 and blood of human patients suffering from malaria was screened to record malarial parasite species. The patients were categorized into 5 different age groups: 1-10 years of age, 11-20 years, 21-30 years, 31-40 years and 41 years and above. Two different methods were adopted to detect malarial cases. [16] A) PCD (Passive Case Detection) technique where blood films were taken from health stations from the patients with symptoms leading to malaria. B) ACD 
(Active Case Detection) where blood films are prepared and collected from the persons with symptoms and signs of malaria during home visits. The blood slides collected using the PCD and ACD [16] techniques were carried to laboratory where these slides were stained with the help of Giemsa's stain. From the keys furnished by [17] identification of species of parasites was made.

\section{Results}

A total 3770 blood smears were prepared from 5 age groups ranging from 1 year to 41 years and above from different localities of Multan District of Southern Punjab during
August 2015 to July 2017. However, due to different localities with different hygienic conditions variations were observed throughout the district Multan.

Out of 3770 cases studied, 1478 cases were found to be of Plasmodium positive counting to $39.02 \%$ of total population studied. Regarding species, Plasmodium vivax was observed to be the highest $905(61.23 \%)$ as compared to that of Plasmodium falciparum $425 \quad(28.75 \%)$ and mixed species (Plasmodium vivax and Plasmodium falciparum) 148 (10.01\%) (Table 1 \& 2).

Table 1. Area-wise prevalence of Malaria infection in Southern Punjab (District Multan)

\begin{tabular}{|c|c|c|c|c|c|c|}
\hline $\begin{array}{l}\text { Sr. } \\
\text { No. }\end{array}$ & Area Name & $\begin{array}{c}\text { No. of } \\
\text { Slides } \\
\text { Examined }\end{array}$ & $\begin{array}{c}\text { Total No. } \\
\text { of } \\
\text { Positivity }\end{array}$ & $\begin{array}{c}\text { Plasmodium } \\
\text { vivax No. and } \\
\%\end{array}$ & $\begin{array}{l}\text { Plasmodium } \\
\text { falciparum } \\
\text { No. and \% }\end{array}$ & $\begin{array}{c}\text { Mixed species } \\
(P \text {. vivax and } \\
P \text {. falciparum } \\
\text { No. and \%) }\end{array}$ \\
\hline 1 & $\begin{array}{c}\text { Shah Rukn-e- } \\
\text { Alam }\end{array}$ & 230 & 42 & 30 & 10 & 2 \\
\hline 2 & $\begin{array}{c}\text { Chowk } \\
\text { Kumharan Wala }\end{array}$ & 280 & 106 & 77 & 20 & 9 \\
\hline 3 & Delhi Gate & 125 & 45 & 25 & 15 & 5 \\
\hline 4 & Pak Gate & 160 & 62 & 40 & 14 & 8 \\
\hline 5 & Haram Gate & 100 & 35 & 22 & 8 & 5 \\
\hline 6 & Bohar Gate & 74 & 20 & 10 & 7 & 3 \\
\hline 7 & Daulat Gate & 82 & 22 & 11 & 8 & 3 \\
\hline 8 & Shuja Abad City & 618 & 290 & 145 & 100 & 45 \\
\hline 9 & Jalal Pur Pirwala & 504 & 118 & 79 & 26 & 13 \\
\hline 10 & Multan Cantt. & 172 & 65 & 34 & 25 & 6 \\
\hline 11 & Dera Adda & 110 & 50 & 31 & 15 & 4 \\
\hline 12 & $\begin{array}{c}\text { Old Shuja Abad } \\
\text { Road }\end{array}$ & 82 & 36 & 23 & 10 & 3 \\
\hline 13 & $\begin{array}{l}\text { Manzoor Abad } \\
\text { Chowk }\end{array}$ & 168 & 90 & 62 & 20 & 8 \\
\hline 14 & Gul Zaib Colony & 124 & 65 & 40 & 20 & 5 \\
\hline 15 & Nawan Shehr & 116 & 58 & 35 & 19 & 4 \\
\hline 16 & Hassan Abad & 60 & 17 & 9 & 6 & 2 \\
\hline 17 & Jahangir Abad & 240 & 95 & 65 & 22 & 8 \\
\hline 18 & Ghanta Ghar & 180 & 82 & 45 & 32 & 5 \\
\hline 19 & Pul Shawala & 130 & 70 & 47 & 20 & 3 \\
\hline 20 & Jalil Abad & 215 & 110 & 75 & 28 & 7 \\
\hline & Total & 3770 & $\begin{array}{c}1478 \\
(39.20 \%)\end{array}$ & $905(61.23 \%)$ & $425(28.75 \%)$ & $148(10.01 \%)$ \\
\hline
\end{tabular}


Table 2. Month-wise prevalence of Malarial infection in Southern Punjab (District Multan)

\begin{tabular}{|c|c|c|c|c|c|}
\hline Month & $\begin{array}{c}\text { No. of } \\
\text { Slides } \\
\text { Examined }\end{array}$ & $\begin{array}{l}\text { Total No. } \\
\text { of } \\
\text { Positivity }\end{array}$ & $\begin{array}{l}\text { Plasmodium } \\
\text { vivax No. } \\
\text { and } \%\end{array}$ & $\begin{array}{l}\text { Plasmodium } \\
\text { falciparum No. } \\
\text { and } \%\end{array}$ & $\begin{array}{c}\text { Mixed Species (P. vivax } \\
\text { and P.falciparum) No. and } \\
\%\end{array}$ \\
\hline $\begin{array}{c}\text { August } \\
2015\end{array}$ & 210 & 85 & 48 & 25 & 12 \\
\hline $\begin{array}{c}\text { September } \\
2015\end{array}$ & 235 & 40 & 22 & 14 & 4 \\
\hline $\begin{array}{c}\text { October } \\
2015\end{array}$ & 122 & 52 & 30 & 17 & 2 \\
\hline $\begin{array}{c}\text { November } \\
2015\end{array}$ & 205 & 63 & 40 & 17 & 6 \\
\hline $\begin{array}{c}\text { December } \\
2015\end{array}$ & 214 & 105 & 70 & 25 & 10 \\
\hline $\begin{array}{c}\text { January } \\
2016\end{array}$ & 274 & 46 & 30 & 12 & 4 \\
\hline $\begin{array}{c}\text { February } \\
2016\end{array}$ & 198 & 55 & 33 & 17 & 5 \\
\hline March 2016 & 174 & 61 & 35 & 18 & 8 \\
\hline April 2016 & 78 & 45 & 26 & 16 & 3 \\
\hline May 2016 & 114 & 66 & 47 & 12 & 7 \\
\hline June 2016 & 110 & 71 & 49 & 16 & 6 \\
\hline July 2016 & 220 & 97 & 62 & 25 & 10 \\
\hline $\begin{array}{c}\text { August } \\
2016 \\
\end{array}$ & 278 & 141 & 90 & 33 & 18 \\
\hline $\begin{array}{c}\text { September } \\
2016\end{array}$ & 87 & 32 & 20 & 10 & 2 \\
\hline $\begin{array}{c}\text { October } \\
2016\end{array}$ & 90 & 34 & 19 & 10 & 5 \\
\hline $\begin{array}{c}\text { November } \\
2016\end{array}$ & 78 & 40 & 25 & 11 & 4 \\
\hline $\begin{array}{c}\text { December } \\
2016\end{array}$ & 222 & 99 & 80 & 13 & 6 \\
\hline $\begin{array}{c}\text { January } \\
2017 \\
\end{array}$ & 108 & 58 & 19 & 34 & 5 \\
\hline $\begin{array}{c}\text { February } \\
2017\end{array}$ & 98 & 37 & 23 & 12 & 2 \\
\hline March 2017 & 97 & 42 & 25 & 14 & 3 \\
\hline April 2017 & 104 & 40 & 23 & 13 & 4 \\
\hline May 2017 & 111 & 35 & 20 & 12 & 3 \\
\hline June 2017 & 128 & 56 & 31 & 19 & 6 \\
\hline July 2017 & 215 & 78 & 38 & 30 & 10 \\
\hline Total & 3770 & 1478 & $905(61.23 \%)$ & $425(28.75 \%)$ & $148(10.01 \%)$ \\
\hline
\end{tabular}

Among children from 1-10 years, 431 slides were examined, out of which 195 (45.24\%) slide positivity of Plasmodium was to be found and the most prevalence species was observed to be Plasmodium vivax 140
(71.79\%) as compared to with that of Plasmodium falciparum 39 (20\%) and mixed species (Plasmodium vivax and Plasmodium falciparum) $16(8.20 \%)$. In the age group of 11-20 years 736 slides were examined and 
$260(35.32 \%)$ slide positivity was to be found and the commonest species of malarial parasites observed was Plasmodium vivax with a highest incidence of $172(66.15 \%)$ as compared to other species of plasmodium such as Plasmodium falciparum 68 (26.15\%) and mixed species (Plasmodium vivax and Plasmodium falciparum) $20 \quad$ (7.69\%). Similarly in the age group of 21-30 years, 820 slides were examined out of which 302 (36.82\%) positivity was to be found and the highest incidence of Plasmodium vivax 190 $(62.91 \%)$ was observed as compared to that of Plasmodium falciparum 90 (29.80\%) and mixed species (Plasmodium vivax and Plasmodium falciparum) 22 (7.28\%). In the age group of $31-40$ years 863 slides were examined and only $306(35.45 \%)$ slides were found to be positive, out of which the highest incidence of Plasmodium vivax 197 (64.37\%) was the commonest species of malarial parasites as compared to Plasmodium falciparum 81 (26.47\%) and mixed species (Plasmodium vivax and Plasmodium falciparum) 28 (9.15\%), while in the age group of 41 years and above 920 slides were observed and $415(45.10 \%)$ slides were found to be positive, out of which 206 (49.63\%) the most common species of malarial parasites was Plasmodium vivax as compared to that of Plasmodium falciparum 147 (35.42\%) and mixed species (Plasmodium vivax and Plasmodium falciparum) 62 (14.93\%) (Table $3)$.

It was also observed that there is seasonal variations in infection of different plasmodium species, as the highest rate of infection of Plasmodium vivax 150 (73.52\%) was noted in December while lowest in September $42(58.33 \%)$ while infection of Plasmodium falciparum was found to be highest in August 58 (25.66\%) and lowest in May $24(23.76 \%)$ as compared to the infection of mixed species (Plasmodium vivax and Plasmodium falciparum) highest in the month of August 30 (13.27\%) and lowest in the month of February 7 (7.60\%) (Table 4). Infection in males was $850(57.51 \%)$, out of which Plasmodium vivax was highest 508 $(59.76 \%)$ as compared to that Plasmodium falciparum 248 (29.17\%) and mixed species (Plasmodium vivax and Plasmodium falciparum) 94 (11.05\%) while in females $628(42.48 \%)$ positivity was to be found, out of which Plasmodium vivax was highest 397 (63.21\%) as compared to that of Plasmodium falciparum 177 (28.18\%) and mixed species (Plasmodium vivax and Plasmodium falciparum) 54 (8.59\%) (Table 5). The comparison of these results with those of other studies which have been done in Pakistan is in discussion.

Table 3. Age-wise overall prevalence of Malarial infection in accordance to Total Number and Percentage in Southern Punjab (District Multan) from August 2015 July 2017

\begin{tabular}{|c|c|c|c|c|c|c|c|}
\hline $\begin{array}{c}\text { Sr. } \\
\text { No. }\end{array}$ & $\begin{array}{c}\text { Age } \\
\text { (Years) }\end{array}$ & $\begin{array}{c}\text { Total } \\
\text { Number } \\
\text { of Slides } \\
\text { Examined }\end{array}$ & $\begin{array}{c}\text { Total } \\
\text { Number } \\
\text { of } \\
\text { Positivity }\end{array}$ & $\begin{array}{c}\text { Overall } \\
\text { Infection }\end{array}$ & $\begin{array}{c}\text { Infection by } \\
\text { Plasmodium } \\
\text { vivax number } \\
\text { and \%age }\end{array}$ & $\begin{array}{c}\text { Infection by } \\
\text { Plasmodium } \\
\text { falciparum } \\
\text { number and } \\
\% \text { age }\end{array}$ & $\begin{array}{c}\text { Mixed species } \\
\text { (Plasmodium } \\
\text { vivax } \text { and } \\
\text { Plasmodium } \\
\text { falciparum }) \\
\text { number and } \\
\text { \%age }\end{array}$ \\
\hline 1 & $1-10$ & 431 & 195 & $45.24 \%$ & $140(71.79 \%)$ & $39(20 \%)$ & $16(8.20 \%)$ \\
\hline 2 & $11-20$ & 736 & 260 & $35.32 \%$ & $172(66.15 \%)$ & $68(26.15 \%)$ & $20(7.69 \%)$ \\
\hline 3 & $21-30$ & 820 & 302 & $36.82 \%$ & $190(62.91 \%)$ & $90(29.80 \%)$ & $22(7.28 \%)$ \\
\hline 4 & $31-40$ & 863 & 306 & $35.45 \%$ & $197(64.37 \%)$ & $81(26.47 \%)$ & $28(9.15 \%)$ \\
\hline 5 & $41-$ & 920 & 415 & $45.10 \%$ & $206(49.63 \%)$ & $147(35.42 \%)$ & $62(14.93 \%)$ \\
\hline Total & above & 3770 & 1478 & $39.20 \%$ & $905(61.23 \%)$ & $425(28.75 \%)$ & $148(10.01 \%)$ \\
\hline
\end{tabular}


Table 4. Month-wise prevalence of Malarial infection in accordance to Total Number and percentage in Southern Punjab (District Multan) from August 2015 to July 2017

\begin{tabular}{|c|c|c|c|c|c|}
\hline Month & $\begin{array}{l}\text { Total number } \\
\text { of slides } \\
\text { examined }\end{array}$ & $\begin{array}{c}\text { Total } \\
\text { number of } \\
\text { positivity }\end{array}$ & $\begin{array}{l}\text { Plasmodium } \\
\text { vivax } \\
\text { number and } \\
\text { \%age }\end{array}$ & $\begin{array}{c}\text { Plasmodium } \\
\text { falciparum number } \\
\text { and \%age }\end{array}$ & $\begin{array}{l}\text { Mixed species } \\
\text { (Plasmodium vivax } \\
\text { and Plasmodium } \\
\text { falciparum number } \\
\text { and \%age }\end{array}$ \\
\hline $\begin{array}{c}\text { August } \\
2015 \& \\
2016\end{array}$ & $\begin{array}{c}210+278=48 \\
8\end{array}$ & $\begin{array}{c}85+141=22 \\
6\end{array}$ & $\begin{array}{c}48+90=138 \\
(61.06 \%)\end{array}$ & $25+33=58(25.66 \%)$ & $12+18=30(13.27 \%)$ \\
\hline $\begin{array}{c}\text { September } \\
2015 \& \\
2016 \\
\end{array}$ & $235+87=322$ & $40+32=72$ & $\begin{array}{c}22+20=42 \\
(58.33 \%)\end{array}$ & $14+10=24(33.33 \%)$ & $4+2=6(8.33 \%)$ \\
\hline $\begin{array}{c}\text { October } \\
2015 \& \\
2016\end{array}$ & $122+90=212$ & $52+34=86$ & $\begin{array}{c}30+19=49 \\
(56.97 \%)\end{array}$ & $17+10=27(31.39 \%)$ & $5+5=10(11.62 \%)$ \\
\hline $\begin{array}{c}\text { November } \\
2015 \& \\
2016\end{array}$ & $205+78=283$ & $63+40=103$ & $\begin{array}{c}40+25=65 \\
(63.10 \%)\end{array}$ & $17+11=28(27.18 \%)$ & $6+4=10(9.70 \%)$ \\
\hline $\begin{array}{c}\text { December } \\
2015 \& \\
2016 \\
\end{array}$ & $\begin{array}{c}214+222=43 \\
6\end{array}$ & $\begin{array}{c}105+99=20 \\
4\end{array}$ & $\begin{array}{c}70+80=150 \\
(73.52 \%)\end{array}$ & $25+13=38(18.62 \%)$ & $10+6=16(7.84 \%)$ \\
\hline $\begin{array}{c}\text { January } \\
2016 \& \\
2017 \\
\end{array}$ & $\begin{array}{c}274+108=38 \\
2\end{array}$ & $46+58=104$ & $\begin{array}{c}30+19=49 \\
(47.11 \%)\end{array}$ & $12+34=46(44.23 \%)$ & $4+5=9(8.65 \%)$ \\
\hline $\begin{array}{c}\text { February } \\
2016 \& \\
2017\end{array}$ & $198+98=296$ & $55+37=92$ & $\begin{array}{c}33+23=56 \\
(60.86 \%)\end{array}$ & $17+12=29(31.52 \%)$ & $5+2=7(7.60 \%)$ \\
\hline $\begin{array}{c}\text { March } \\
2016 \& \\
2017 \\
\end{array}$ & $174+97=271$ & $61+42=103$ & $\begin{array}{c}35+25=60 \\
(58.25 \%)\end{array}$ & $18+14=32(31.06 \%)$ & $8+3=11(10.67 \%)$ \\
\hline $\begin{array}{l}\text { April } 2016 \\
\& 2017\end{array}$ & $78+104=182$ & $45+40=85$ & $\begin{array}{c}26+23=49 \\
(57.64 \%)\end{array}$ & $16+13=29(34.11 \%)$ & $3+4=7(8.23 \%)$ \\
\hline $\begin{array}{c}\text { May } 2016 \\
\& 2017\end{array}$ & $\begin{array}{c}114+111=22 \\
5\end{array}$ & $66+35=101$ & $\begin{array}{c}47+20=67 \\
(66.33 \%)\end{array}$ & $12+12=24(23.76 \%)$ & $7+3=10(9.90 \%)$ \\
\hline $\begin{array}{l}\text { June } 2016 \\
\& 2017\end{array}$ & $\begin{array}{c}110+128=23 \\
8\end{array}$ & $71+56=127$ & $\begin{array}{c}49+31=80 \\
(62.99 \%)\end{array}$ & $16+19=35(27.55 \%)$ & $6+6=12(9.44 \%)$ \\
\hline $\begin{array}{c}\text { July } 2016 \\
\& 2017\end{array}$ & $\begin{array}{c}220+215=43 \\
5\end{array}$ & $97+68=175$ & $\begin{array}{c}62+38=100 \\
(57.14 \%)\end{array}$ & $25+30=55(31.42 \%)$ & $10+10=20(11.42 \%)$ \\
\hline Total & $\begin{array}{c}2154+1616= \\
3770\end{array}$ & $\begin{array}{c}786+692=1 \\
478 \\
(39.20 \%)\end{array}$ & $\begin{array}{c}492+413=90 \\
5(61.23 \%)\end{array}$ & $\begin{array}{c}214+211=425 \\
\quad(28.75 \%)\end{array}$ & $80+68=148(10.01 \%)$ \\
\hline
\end{tabular}


Table 5. Sex-wise prevalence of Malarial Infection in accordance to Total Number and Percentage in Southern Punjab (District Multan) from August 2015 to July 2017

\begin{tabular}{|c|c|c|c|c|c|c|c|}
\hline \multirow[b]{2}{*}{$\begin{array}{c}\text { Total } \\
\text { Number } \\
\text { of Slides } \\
\text { Examine } \\
\mathrm{d}\end{array}$} & \multirow[b]{2}{*}{$\begin{array}{c}\text { Total } \\
\text { Number } \\
\text { of } \\
\text { Positivit } \\
\text { y }\end{array}$} & \multicolumn{3}{|c|}{ Number of Male Positive } & \multicolumn{3}{|c|}{ Number of Female Positive } \\
\hline & & $\begin{array}{l}\text { Plasmodiu } \\
\text { m vivax }\end{array}$ & $\begin{array}{c}\text { Plasmodiu } \\
m \\
\text { falciparum }\end{array}$ & $\begin{array}{c}\text { Mixed } \\
\text { Species } \\
\text { (Plasmodiu } \\
\text { m vivax and } \\
\text { Plasmodiu } \\
m \\
\text { falciparum }\end{array}$ & $\begin{array}{l}\text { Plasmodiu } \\
\text { m vivax }\end{array}$ & $\begin{array}{c}\text { Plasmodiu } \\
m \\
\text { falciparum }\end{array}$ & $\begin{array}{c}\text { Mixed } \\
\text { Species } \\
\text { (Plasmodiu } \\
\text { m vivax and } \\
\text { Plasmodiu } \\
m \\
\text { falciparum }\end{array}$ \\
\hline \multirow{2}{*}{3770} & \multirow{2}{*}{1478} & $\begin{array}{c}508 \\
(59.76 \%)\end{array}$ & $\begin{array}{c}248 \\
(29.17 \%)\end{array}$ & $\begin{array}{c}94 \\
(11.05 \%)\end{array}$ & $\begin{array}{c}397 \\
(63.21 \%)\end{array}$ & $\begin{array}{c}177 \\
(28.18 \%)\end{array}$ & $\begin{array}{c}54 \\
(8.59 \%) \\
\end{array}$ \\
\hline & & \multicolumn{3}{|c|}{$\begin{array}{c}850 \\
(57.51 \%)\end{array}$} & \multicolumn{3}{|c|}{$\begin{array}{c}628 \\
(42.48 \%) \\
\end{array}$} \\
\hline
\end{tabular}

\section{Discussion}

In Pakistan, malaria is considered to be a continuous severe public health problem [18]. From the Eastern Mediterranean region in 2010, over one million malarial cases through microscopy confirmed were reported of which $25 \%$ came from Pakistan [1]. Approximately 325 million people affect through malaria and causes more than a million of deaths per year throughout the world. Plasmodium falciparum has high mortality as compared to other plasmodium and it causes several diseases such as algid malaria, renal failure and cerebral malaria [5].

This survey was conducted to provide up to date information about malarial prevalence throughout District Multan. In this analysis, samples were collected from patients suffering from malaria with symptoms and one limitation is the potential for district Multan region in accordance to treatment seeking behaviour and centres for access to treatment. But unfortunately prior to diagnosis information on treatments taken was not collected and could be included in this study. In addition to this, season variations were also to be noted in the district areas of Multan where the highest rate of infection of Plasmodium vivax in December, Plasmodium falciparum in August and mixed species (Plasmodium vivax and Plasmodium falciparum) in August. Despite this information, the data presented in this study is more comprehensive and shows current characterization of prevalence of malaria in Multan District than has previously been available.

The prevalence of Plasmodium vivax was observed as highest (61.23\%) as compared to that of Plasmodium falciparum (28.75\%) and mixed species (Plasmodium vivax and Plasmodium falciparum) $(10.01 \%)$ in the present study. Many researchers reported higher incidences of Plasmodium vivax (60.4\%), Plasmodium falciparum $(37.6 \%)$ in District of Multan, while in districts Quetta (66.7\% Plasmodium vivax, $30.8 \%$ Plasmodium falciparum), Muzafarabad (90.3\% Plasmodium vivax, $48.2 \%$ Plasmodium falciparum) and Kohlu (58.8\% Plasmodium vivax and $41.2 \%$ Plasmodium falciparum) [13, 19-21] respectively.

In the present analysis, Plasmodium vivax $71.79 \%, 66.15 \%, 62.91 \%, 64.37 \%$ and $49.63 \%$ was observed in the patients of the age group 1-10, 11-20, 21-30, 31-40, and 41 years \& above respectively. Similarly, Plasmodium falciparum 20\%, 26.15\%, $29.80 \%, 26.47 \%$ and $35.42 \%$ was observed in the age group 1-10, 11-20, 21-30, 31-40, and 41 years \& above, while mixed species 
(Plasmodium vivax and Plasmodium falciparum) $8.2 \%, 7.69 \%, 7.28 \%, 9.15 \%$ and $14.93 \%$ was observed in the age group 1-10, $11-20,21-30,31-40$, and 41 years \& above respectively. Similarly [22] found $8.5 \%$ and $73.8 \%$ in the patients of the age group of 1120 years and 21 years \& above respectively in the Kashmiri settled in Muzaffarabad and Plasmodium falciparum 18\%, 22.4\%, 26.1\% and $33.5 \%$ in the age group of 1-10, 11-20, 21-30 and 31-40 years was observed in the refugees of Zhob respectively [23].

In the malarial patients of Iran, slide positivity rate was to be reported $9.7 \%$ [24]. 43.3, 33.3; 16.1, 15.5; 33.9, 11.5; 25.5, 28.5; $27.2, \quad 41.7 \%$ slide positivity rate of Plasmodium vivax and Plasmodium falciparum in Kharan, Quetta, Qila Abdullah, Mastung and Khuzdar rural and urban areas respectively by [13, 14, 19-21, 27]. In another study in 33 different localities of Quetta (city) visited showed that $P$. vivax was found to be the most common species with the highest rate of frequency $(84.53 \%)$ as compared to that of P. falciparum $(6.02 \%)$ in children [28]. These results are similar with our findings.

In this study, mixed infection of $8.2 \%$, $7.69 \%, 7.28 \%, 9.15 \%$ and $14.93 \%$ was observed. Mixed infection on $2.4 \%$ was observed in Multan district by [25]. However, in Quetta district, the same 2.4\% was observed [26].

During this study no case of Plasmodium ovale or Plasmodium malariae infection was to be observed and the same were the observations of [25] in District Multan.

\section{Conclusion}

Pakistan is facing several challenges in the control and management of malaria including lack of diagnostic facilities, misdiagnosis and use of presumptive treatments. The results of this study indicate that Plasmodium infection in Pakistan are largely attributed to Plasmodium vivax but Plasmodium falciparum and mixed species of Plasmodium infections are also prevalent. In addition to this, regional variation in the prevalence and species composition of malaria is very high. So, malaria control efforts should be focused where malaria prevalence is highest with emphasis on improving species diagnosis.

\section{Authors' contributions}

Conceived and designed the experiments: $\mathrm{M}$ Zafar, Laboratory Experiment: M Zafar \& Asmatullah, Data Collection: MKA Khan \& MZ Khan, Analysis of Data: IM \& S Masud, Experiment Supervision: Asmatullah, Paper Writing: M Zafar.

\section{References}

1. Organization WH (2010). Report on the fourth malaria border coordination meeting between Afghanistan, Islamic Republic of Iran and Pakistan, Islamabad, Pakistan, 29 September-1 October 2009.

2. Organization WH (2005). The World Health Report 2005: Make every mother and child count, World Health Organization.

3. Korenromp E (2005). Malaria incidence estimates at country level for the year 2004. Proposed estimates and draft report. World Health Organization, Roll Back Malaria, MERG Task Force on Malaria Morbidity.

4. Crawley J, Chu C, Mtove G \& Nosten F (2015). Malaria in children. The Lancet 375: 1468-1481.

5. Bhalli M (2001). Falciparum malaria-a review of 120 cases. J-College of Phy and Surgeons of Pak 11: 300-303.

6. Muhammad N \& Hussain A (2011). Prevalence of malaria in general populationof distric buner. $J$ of Postgraduate Medical Institute (Peshawar-Pakistan), pp 17.

7. Jalal-Ud-Din KS \& Ally SH (2006). Malaria in children: study of 160 cases at a private clinic in Mansehra. J Ayub Med Coll Abbottabad 18: 44-45.

8. Mahmood KH (2005). Malaria in Karachi and other areas in Sindh. Pak Armed Forces Med J 55: 345-348. 
9. Nizamani A, Kalar N \& Khushk I (2006). Burden of malaria in Sindh, Pakistan: a two years surveillance report. Jlumhs 5: 76-83.

10. Saleem I, Pirzada A \& Rahman R (2006). Noor-ul-Iman. Cerebral malaria: an experience in NWFP, Pakistan. Pak J Med Sci 14: 35-9.

11. Idris M, Sarwar J \& Fareed J (2007). Pattern of malarial infection diagnosed at Ayub Teaching Hospital Abbottabad. $J$ Ayub Med Coll Abbottabad 19: 35-6.

12. Durrani A, Durrani I, Abbas N \& Jabeen M (1997). Epidemiology of cerebral malaria and its mortality. JPMA; The $J$ of the Pak Medical Assoc 47: 213-215.

13. Yasinzai MI \& Kakarsulemankhel JK (2003). Incidence of malaria infection in rural areas of District Quetta, Pakistan. On Line J Med Sci 3: 766-72.

14. Yasinzai MI \& Kakarsulemankhel JK (2008). Incidence of human malaria infection in desert area of Pakistan: District Kharan. J of Agri and Social Sci (Pak).

15. Khan AR, Khan N \& Khan H (2018). Frequency of slide positivity in clinically suspected malaria cases. Gomal $J$ of Medical Sci 12(118-20). Malaria Control Program, Balochistan, Survey Report of 2016-2017, pp 1.

16. Manson-Bahr PH (1946). Manson's Tropical Diseases: A Manual of the Diseases of Warm Climates. Academic Medicine 21: 318.

17. Paniker CJ (2007). Textbook of medical parasitology, Jaypee Brothers Medical Publishers (P) Ltd.

18. Qayum M, Zahur H, Ahmad N, Ilyas M, Khan A \& Khan S (2012). SPHERE-based assessment of knowledge and preventive measures related to malaria among the displaced population of Jalozai, Pakistan. JPMA-J of the Pak Medical Assoc 62: 344.
19. Yasinzai MI \& Kakarsulemankhel JK (2008). Incidence of human malaria infection in northern hilly region of Balochistan, adjoining with NWFP, Pakistan: district Zhob. Pak J Biol Sci 11: 1620-1624.

20. Yasinzai MI \& Kakarsulemankhel JK (2008). Incidence of human malaria infection in Barkhan and Kohlu, bordering areas of East Balochistan. Pak $J$ of Medical Sci 24: 306.

21. Yasinzai MI \& Kakarsulemankhel JK (2007b). Incidence of human malaria infection in central areas of Balochistan: Mastung and Khuzdar. Rawal Medical J 32: 176-178.

22. Jan A \& Kiani T (2001). Haematozoan parasites in Kashmiri refugees. Pak J Med Res 40: 10-12.

23. Khadim M (2002). Malaria a menace at Zhob Garrison. Pak Armed Forces Med J 52: 203-207.

24. Karimi-Zarch A, Mahmoodzadeh A \& Vatani H (2006). A survey on malaria and some related factors in south east of Caspian Sea. Pak J Med Sci 22: 489-92.

25. Yar H, Masood K, Maqbool A \& Malik G (1998). Prevalence of malarial parasite species in Multan district. The Professional 5: 183-7.

26. Sheikh AS, Sheikh A, Sheikh N \& Paracha $\mathrm{S}$ (2005). Endemicity of malaria in Quetta. Pak J of Medical Res 44: 7.

27. Yasinzai MI \& Kakarsulemankhel JK (2007). Incidence of malaria infection in Pak-Afghan border area of Pakistan: District Qilla Abdullah-Chaman. Hamdard Medicus October 62-66.

28. Sumbal A, Iqbal MY, Naseem M \& Khan L (2017). Frequency of Plasmodium vivax and Plasmodium falciparum in school going children of Quetta (City), Balochistan 13(6): 43-50. 